\title{
Evaluation of Polymerase Chain Reaction (PCR)-Based Methods for Rapid, Accurate Detection and Monitoring of Verticillium dahliae in Woody Hosts by Real-Time PCR
}

\author{
Baker Aljawasim and Paul Vincelli, Department of Plant Pathology, University of Kentucky, Lexington 40546-0312
}

\begin{abstract}
Aljawasim, B., and Vincelli, P. 2015. Evaluation of polymerase chain reaction (PCR)-based methods for rapid, accurate detection and monitoring of Verticillium dahliae in woody hosts by real-time PCR. Plant Dis. 99:866-873.

Verticillium wilt, caused by Verticillium dahliae, is one of the most economically important diseases of woody hosts such as ash (Fraxinus spp.), sugar maple (Acer saccharum), and redbud (Cercis canadensis). The causal agent has a broad host range, including not only woody hosts but also important vegetable and field crops, and it is distributed worldwide. Diagnosis of $V$. dahliae in infected woody hosts is often based on the occurrence of vascular discoloration and time-consuming isolation. However, not all woody hosts exhibit vascular discoloration, and not all vascular discoloration symptoms are due to infection by $V$. dahliae. In this study, real-time polymerase chain reaction (PCR)-based assays were evaluated and employed for rapid and accurate detection of $V$. dahliae in different woody hosts. High-quality DNA was extracted in large quantities

from presumptively infected woody hosts by collecting drill-press shavings from sample tissue, bead beating, and extracting using a cetyltrimethylammonium bromide method. Six published primer sets were evaluated against genomic DNA of $V$. dahliae as well as selected negative controls, and two sets (VertBt-F/VertBt-R and VDS1/VDS2) showed promise for further evaluation using DNA extracts from field samples. The VertBt primers amplified a species-specific 115-bp fragment of the expected size, while the VDS primers amplified the expected specific 540-bp fragment. However, the VertBt primer set exhibited higher sensitivity in detection of $V$. dahliae even in asymptomatic trees. The PCR-based methods developed here could be used as rapid tools for pathogen detection and monitoring, thus informing plant pathogen management decisions.
\end{abstract}

For the purposes of research or diagnosis, hosts infected by Verticillium dahliae Kleb. exhibit specific symptoms that are used to presumptively diagnose the disease, including external symptoms (wilt, chlorosis, necrosis, and dieback) and internal symptoms (vascular discoloration). However, foliar disease symptoms are not a reliable indicator of infection by $V$. dahliae, because the symptoms it induces may also result from a variety of biotic and abiotic stresses (30). For instance, cold winters may cause symptoms on twigs which are similar to Verticillium wilt symptoms. Also, vascular discoloration may be used as an indicator of $V$. dahliae infection but certain fungi and abiotic stresses can cause the same symptoms as well (11). Conversely, the fungus can be isolated from sapwood which exhibits no vascular discoloration (3). Therefore, vascular discoloration should not be relied on for diagnosis, either $(2,28)$. Another technique used to detect $V$. dahliae in woody hosts is based on isolation of the fungus in pure culture, a process that can take several days. Furthermore, using selective media to isolate $V$. dahliae can be challenging because Verticillium spp. grow slowly compared with other microorganisms which may overrun plates before $V$. dahliae colonies can be detected (5). In addition, dormancy of microsclerotia or inhibition of growth of $V$. dahliae by other microorganisms on media may cause variable and false-negative results (19). Although isolation in culture can be a useful tool for detecting this fungus from some hosts, it is not commonly successful from certain hosts, such as green ash and olive (3). Given this, a rapid and accurate realtime polymerase chain reaction (PCR)-based assay for detection of $V$. dahliae in woody hosts would be of great value.

Corresponding author: P. Vincelli; E-mail: pvincell@uky.edu

*The $\boldsymbol{e}$-Xtra logo stands for "electronic extra" and indicates that four supplementary figures are included in the online edition.

Accepted for publication 2 October 2014.

Modified: 29 Sep 2015.

http://dx.doi.org/10.1094/PDIS-05-14-0528-RE

(C) 2015 The American Phytopathological Society
PCR has emerged as a powerful pathogen detection method in crop sciences, including certification programs, plant quarantine, pathogen identification and diagnosis, disease management, and crop production (21). Using specific primers to amplify a particular DNA target from a species of interest is the cornerstone of a PCR-based diagnostic assay (15). PCR offers several advantages over traditional detection methods because it does not require isolation and culturing of the fungus from infected plant tissues. Furthermore, PCR typically is sensitive, rapid, and reliable (15,34). Real-time PCR was developed for even faster detection and as well as for quantification of plant pathogens, including bacteria, viruses, and fungi (23). Compared with conventional PCR, real-time PCR techniques offer advantages, including reduced contamination risks, eliminating the need for ethidium bromide staining, and eliminating the time and cost of gel electrophoresis (25). In recent years, several PCR-based assays have been used to identify and quantify $V$. dahliae on different hosts $(4,7,10,12,14,15,27,32)$. However, to our knowledge, existing PCR primer/probe sets have not been compared, and none of those assays were tested against infected woody plants.

The objectives of this research were to (i) evaluate published pairs of species-specific primers for detecting $V$. dahliae, in order to develop a rapid and accurate tool for detection and screening for the presence of $V$. dahliae in various woody hosts; and (ii) evaluate methods of disrupting woody tissues for extraction of total sample DNA.

\section{Materials and Methods}

Pathogen isolates. In all experiments, four isolates of $V$. dahliae, one isolate of V. albo-atrum, and isolates of Phytophthora capsici and Pyricularia oryzae (serving as additional negative controls) were used to develop a PCR assay specific for $V$. dahliae (Table 1). All isolates were maintained as conidia or mycelia at $-80^{\circ} \mathrm{C}$ in potato dextrose broth (PDB) with $50 \%$ (vol/vol) glycerol, and they were grown on potato dextrose agar (PDA) for 3 days by pipetting $25 \mu$ l of the glycerol spore suspension onto PDA plates. The identification of Verticillium isolates was confirmed by morphological analysis and by direct sequencing of both internal transcribed spacer regions and amplicons generated using VMSP primers (22).

DNA extraction. Pathogen isolates were grown at room temperature for 10 days in petri dishes containing PDA. Plugs were 
aseptically cut from the actively growing margins of the fungus colonies and transferred into flasks containing 20 to $25 \mathrm{ml}$ of sterile PDB. After 7 days of incubation in the dark at room temperature, mycelium was harvested by filtering through sterile Whatman number 1 filter paper and rinsing with sterile distilled water. Approximately $100 \mathrm{mg}$ of mycelium (fresh weight) was added to 2.0-ml screw-cap microcentrifuge tubes containing two 4- to 6-mm sterile glass beads. Then, mycelium was frozen in liquid nitrogen and ground into a fine powder using a bead-beater at 2,500 rpm for $30 \mathrm{~s}$ (Mini-Bead Beater, Biospec Products 3110BX; Bartlesville, OK). For DNA extraction, the pulverized mycelium was suspended in $1 \mathrm{ml}$ of extraction buffer, consisting of $2 \%$ (wt/vol) cetyltrimethyl ammonium bromide (CTAB), $2 \%$ (wt/vol) polyvinylpyrrolidone (PVP40), $100 \mathrm{mM}$ Tris- $\mathrm{HCl}(\mathrm{pH} 8)$, $1.4 \mathrm{mM} \mathrm{NaCl}, 20 \mathrm{mM}$ EDTA (pH 8), with $2 \mu \mathrm{l}$ of 2-mercaptoethanol and $10 \mu \mathrm{l}$ of Qiagen RNase A solution at $100 \mathrm{mg} / \mathrm{ml}$ added immediately before mixing. The solution was mixed by vortexing and incubated at $65^{\circ} \mathrm{C}$ for $15 \mathrm{~min}$ with gentle mixing one to three times during the incubation, followed by microcentrifugation at $10,400 \mathrm{rpm}$ for $10 \mathrm{~min}$. After centrifugation, $650 \mu \mathrm{l}$ of the supernatant was transferred to a $1.5-\mathrm{ml}$ microcentrifuge tube and mixed with an equal volume of 24:1 ( $\mathrm{vol} / \mathrm{vol})$ chloroform/isoamyl alcohol. The solution was centrifuged at $12,500 \mathrm{rpm}$ for $10 \mathrm{~min}$. Then, $500 \mu \mathrm{l}$ of the supernatant was transferred to a $1.5-\mathrm{ml}$ microcentrifuge tube containing $350 \mu \mathrm{l}$ of isopropanol, gently mixed, and centrifuged at $12,500 \mathrm{rpm}$ for $10 \mathrm{~min}$. Pellets were dissolved in $100 \mu \mathrm{l}$ of surplus Buffer AE from the Qiagen DNeasy kit (10 mM Tris and 0.5 Mm EDTA, $\mathrm{pH} 9.0)$. The resuspended DNA was stored in a $-20^{\circ} \mathrm{C}$ freezer $(20,22)$.

Evaluation of published specific primer sets for $V$. dahlia. Several published primer sets specific for $V$. dahliae (Table 2) were evaluated against known $V$. dahliae isolates originally obtained from infected woody hosts (Table 1). The specificity of all primer sets was evaluated by real-time PCR in $25-\mu 1$ reaction volumes in a Cepheid Smart Cycler II thermocycler. All primer sets were evaluated using thermocycling conditions specified in the references cited in Table 2. Four of six primer sets (VertBt-F/VertBt-R, VDS1/VDS2, VMSP/VMSP2, and DB19/DB22) were tested using SYBR Green as a reporter dye. The reaction mixture contained $20 \mathrm{ng}$ of DNA template, $1 \times$ PCR buffer, $0.5 \mathrm{U}$ of Titanium Taq, $0.2 \mathrm{mM}$ dNTPs (Promega Corp.), $0.2 \mu \mathrm{M}$ each primer, $0.5 \times$ SYBR Green, $5 \mu \mathrm{l}$ Smart Cycler Additive Reagent (a mixture of bovine serum albumin, trehalose, and Tween-20), and sterile molecular-grade water to $25 \mu$ l. As a negative control, sterile molecular-grade water substituted for DNA template. In all assays, which were performed at least twice, reaction products were resolved in $1.5 \%(\mathrm{wt} / \mathrm{vol})$ agarose gel, and the fragments were visualized under UV fluorescence after staining with ethidium bromide. Fragment sizes were estimated using a 100-bp DNA O'Gene Ruler ladder. Also, for SYBR Green-based assays, melt curve analysis (ramp rate $0.2^{\circ} \mathrm{C} / \mathrm{s}$ ) was used to evaluate for potential primer dimers, nonspecific amplification, and amplification of target amplicons from $V$. dahliae, V. albo-atrum, Phytophthora capsici, and Pyricularia oryzae. Three primer sets were tested with their associated Taqman probe (each labeled with 6-FAM (Fluorescein) and Black Hole Quencher-1): DB19 plus DB22 with probe espdf01, Vd-F929-947 plus Vd-R1076-1094 with $V$. dahliae probe, and VTP1-2F plus VTP1-2R with VTP1-2P probe, as described by the authors of these primer sets (Table 2).

Real-time PCR sensitivity. The sensitivity of two primer sets (VertBt-F/VertBt-R andVDS1/VDS) was evaluated over a range of concentrations of $V$. dahliae DNA in both the presence and absence of $2 \mathrm{ng}$ of DNA extracted from a maple tree previously shown by real-time PCR (VertBt primers) to be uninfected by $V$. dahliae. Concentrations of DNA of $V$. dahliae isolate 876 tested were $20 \mathrm{ng}, 2 \mathrm{ng}$, $0.2 \mathrm{ng}, 0.02 \mathrm{ng}, 2 \mathrm{pg}, 0.2 \mathrm{pg}, 0.02 \mathrm{pg}$, and $2 \mathrm{fg}$ per $25-\mu 1$ reaction, along with a DNA-free control. Results were evaluated using cycle threshold $\left(\mathrm{C}_{\mathrm{t}}\right)$ values and melt curve analysis.

Disruption of woody plants tissue and its impact on DNA extraction. Twig segments, 20 to $30 \mathrm{~cm}$ in length, were removed from a maple (Acer sp.) and an ash (Fraxinus sp.) tree located on the campus of the University of Kentucky, Lexington; these were surface sterilized with undiluted household bleach. Only twigs subsequently determined to be PCR-negative using the Vert-Bt primers were used in these tests. One set of samples from each tree species tested was fresh and another was tested after oven drying for 2 days at $82^{\circ} \mathrm{C}$. Bark and phloem were removed under aseptic conditions to avoid contamination with other extraneous DNA (33). Xylem tissue was mechanically disrupted in a two-by-three factorial design, with two levels of primary disruption and three levels of secondary disruption, as follows. For each twig sample, initial ("primary") xylem tissue disruption was performed in one of two ways, both of which resulted in small wood shavings. For primary disruption method 1, xylem was exposed by shaving using a mechanical pencil sharpener (American Pencil Sharpener Company standard sharpener); all shavings obtained were mixed and processed as described below. To minimize crosscontamination between samples, the shaving head was thoroughly washed in a detergent solution and rinsed in water (16). For primary disruption method 2 , xylem was drilled using a $0.3-\mathrm{cm}$ drill bit to generate shavings, which were mixed and processed as described below. The bit was washed with ethanol $(70 \% \mathrm{vol} / \mathrm{vol})$ to minimize crosscontamination among samples.

After primary xylem disruption, three methods of secondary xylem tissue disruption (pulverization) were evaluated on samples of shavings from each primary disruption method. For secondary disruption method 1 , approximately $100 \mathrm{mg}$ of wood shavings (obtained from primary tissue disruption) were added to a mesh plastic bag (item number ACC00930/0100; Agdia Inc.), and mixed with $3 \mathrm{ml}$ of CTAB buffer, $2 \mu$ l of mercaptoethanol, and $10 \mu \mathrm{l}$ of RNase at $100 \mathrm{mg} / \mathrm{ml}$. This mixture was mashed for 2 to $3 \mathrm{~min}$ using a drill press fitted with a ball-bearing tool (Tissue Homogenizer, item number ACC 00900; Agdia Inc.) designed to compress the mesh bags. Homogenate $(1 \mathrm{ml})$ was added to a $1.5-\mathrm{ml}$ microcentrifuge tube and DNA was extracted using the CTAB method described above. For secondary disruption method 2, wood shavings were ground into a fine powder using a Mini-BeadBeater-1, (Biospec Products 3110BX) by adding $100 \mathrm{mg}$ of wood shavings and two $6.3-\mathrm{mm}$ sterile glass beads (Biospec product) to a sterile 2-ml bead-beater tube (catalog number 72.693; Sarstedt), flash freezing in liquid nitrogen for $2 \mathrm{~min}$, and shaking in a Mini-BeadBeater-1 for $30 \mathrm{~s}$ at 4,200 rpm. DNA was extracted using the CTAB method, as described above. Secondary disruption method 3 was a control, with DNA extraction from shavings resulting from primary tissue disruption only, with no secondary tissue disruption.

Following DNA extraction using the CTAB method described above, the concentration of DNA obtained was quantified using an Invitrogen Qubit fluorometer (Life Technologies), as per the manufacturer's instructions (www.probes.invitrogen.com/qubit). Resulting DNA concentrations were subjected to an analysis of variance

Table 1. Species, host of origin, year of isolation, location, and source of isolates of Verticillium dahliae, V. albo-atrum, Phytophthora capsici, and Pyricularia oryzae used to evaluate the specificity of published primer sets to detect $V$. dahliae in woody hosts

\begin{tabular}{|c|c|c|c|c|c|}
\hline Species & Isolate designation & Host of origin & Year of isolation & Location & Source \\
\hline V. dahliae & 876 & Maple (Acer sp.) & 2006 & Fitchburg, Dane County, WI & K. Subbarao \\
\hline V. dahliae & 884 & Ash (Fraxinus sp.) & 2006 & Nashoteh, Waukesha County, WI & K. Subbarao \\
\hline V. dahliae & 891 & Maple (Acer sp.) & 2006 & Waukesha County, WI & K. Subbarao \\
\hline V. dahliae & 64114 & Maple (Acer sp.) & 2003 & Illinois & ATCC $^{\mathrm{a}}$ \\
\hline V. albo-atrum & V.10, IPP & Irish potato (Solanum tuberosum) & Unknown & Wisconsin & A. Tiedemann \\
\hline Phytophthora capsici & 01-2011-G & Pumpkin (Cucurbita pepo) & 2001 & Kentucky & B. Amsden \\
\hline Pyricularia oryzae & KY-96 & Perennial ryegrass (Lolium sp.) & 1996 & Lexington, KY & P. Vincelli \\
\hline
\end{tabular}

a American Type Culture Collection. 
following a two-by-three factorial design, with primary and secondary tissue disruption techniques as variables.

Evaluation for real-time PCR inhibition. The potential for PCR inhibition is high because woody plant tissues often contain high concentrations of phenolic compounds and polysaccharides inhibitory to DNA polymerase enzymes used in PCR $(6,13,26)$. During PCR, false negatives can result from the presence of PCR inhibitors coextracted with DNA obtained from plant tissue. Real-time PCR tests for this were conducted using the VertBt and VDS primer sets and extracts of woody plants. DNA extracts were obtained using the CTAB method described above, from samples collected from six species determined to be PCR-negative using the VertBt primers: sugar maple (Acer saccharum), ash (Fraxinus sp.), oak (Quercus pubescens), redbud (Cercis canadensis), crabapple (Malus sp.), and barberry (Hydrastis canadensis). To test for inhibition, PCR reactions containing $3 \mu \mathrm{l}$ of DNA extract from woody plants plus $20 \mathrm{ng}$ of genomic DNA of $V$. dahliae isolate 876 were compared with reactions containing $20 \mathrm{ng}$ of $V$. dahliae alone. The nuclei of $V$. dahliae are haploid and mycelial cells are generally monokaryotic; therefore, adding $20 \mathrm{ng}$ of genomic DNA per PCR reaction was equivalent to $5.44 \times$ $10^{5}$ copies of PCR target molecules, which would represent the DNA in $5.44 \times 10^{5}$ cells of $V$. dahliae. PCR reactions were compared using $C_{t}$ values and melt curve analysis.

Application of selected real-time PCR assays to field-grown trees. Samples were collected from two sugar maple trees exhibiting symptoms of wilt, chlorosis, epinasty, and stunting but no vascular discoloration; these were obtained from a horse farm in Lexington, Fayette County, KY. Two asymptomatic trees were sampled from the same location. In addition, two 5-year-old smoke trees (Cotinus coggygria) with foliar symptoms typical of Verticillium wilt and with vascular discoloration were sampled from Frankfort, KY. Eight twigs $(40 \mathrm{~cm})$ were arbitrarily collected from different positions of each tree and surface sterilized in $0.04 \%$ (vol/vol) $\mathrm{NaOCl}$ for $5 \mathrm{~min}$. Next, sample tissue was shaved using a drill bit, followed by pulverization using the beadbeater; then, DNA extraction was conducted as described above. Extracted DNA from each twig was tested using the VertBt and VDS primer sets. All samples obtained from trees were tested for the presence of PCR inhibition by comparing $C_{t}$ values obtained using DNA extract from known $V$. dahliae isolate 876 with that obtained in tubes containing DNA of both $V$. dahliae 876 plus sample DNA, in order to test for false-negative reactions with these samples. Shavings from several twigs were aseptically plated onto $1.5 \%$ (wt/vol) water agar medium and incubated in darkness at room temperature for 12 days. Colonies of $V$. dahliae were identified based on colony morphology. In addition to these assays, both primer sets were tested against nine woody samples suspected (based on symptoms and host) to be affected by Verticillium wilt and submitted to the University of Kentucky Plant Diagnostic Laboratory. All such samples were tested by real-time PCR using the same two primer sets. Testing for the presence of PCR inhibitors was conducted as described above.

Confirmation of target amplicon generated using VertBt and VDS primer sets. In order to verify the fidelity of the two most promising primer sets in this study (the VertBt and VDS sets), amplicons that were obtained from several PCR-positive woody samples were evaluated. For confirmation of the fidelity of the VDS primers, two PCR-positive samples (numbers 781 and 2188) were amplified using the VDS primer set. Then, amplicons generated using the VDS primer set were confirmed by direct DNA sequencing after purifying the amplicon from agarose gels using QIAquick Gel Extraction Kit (Qiagen number 28704) (1). For VertBt primers, direct sequencing was unsuccessful due to amplicon shortness; therefore, confirmation of amplicon identity was done using restriction enzyme analysis. NEBcutter version 1.0 (http://tools.neb.com/NEBcutter) was used to identify enzyme restriction sites and predict fragment sizes for the expected amplicon. This analysis was conducted with a sequence of the $V$. dahliae $\beta$-tubulin gene (accession number DQ840573.1) downloaded from the National Center for Biotechnology Information (NCBI) database (http://blast.ncbi.nlm.nih.gov/Blast.cgi). The restriction enzyme HaeIII, which recognizes the sequence $5^{\prime} \ldots$ GGCC.... $3^{\prime}$, was chosen to cleave the 115-bp amplicon into expected fragments of 58 and $57 \mathrm{bp}$ in length. Restriction reactions were conducted as recommended by the manufacturer (New England BioLab Inc.), using $100 \mathrm{ng}$ of amplicon per reaction. The restriction enzyme products were visualized in $3 \%$ agarose gel by UV- fluorescence after staining with ethidium bromide, and compared with a 100-bp DNA O'Gene LR ladder.

\section{Results}

Evaluation of published primer sets specific for V. dahliae. All primer sets were evaluated against a set of isolates of Verticillium spp., and these primer sets provided mixed results. The SYBR Green-based assay using the VertBt primer set amplified all isolates of $V$. dahliae with $\mathrm{C}_{\mathrm{t}}$ values between 16 and 22 ; amplification was also observed in the negative controls and with the $V$. albo-atrum isolate $\left(C_{t}\right.$ values for both positive and negative controls were in the range of 16 to 28 ). However, the melt derivative curves revealed the species specificity of this assay by showing the melt temperatures for amplicons of all $V$. dahliae isolates, which were approximately $86^{\circ} \mathrm{C}$, whereas all the negative controls plus the $V$. albo-atrum isolate

Table 2. Primer name, sequences, molecular target, fragment length, and citation of all specific primers and probes for Verticillium dahliae evaluated in this study

\begin{tabular}{|c|c|c|c|c|c|}
\hline Oligo name & Oligo sequence $\left(\mathbf{5}^{\prime}-\mathbf{3}^{\prime}\right)$ & Target & $\begin{array}{l}\text { Fragment } \\
\text { length (bp) }\end{array}$ & Thermocycling conditions & Citation \\
\hline VMSP1 & CATAAAAGACTGCCTACGCCG & \multirow[t]{2}{*}{ rDNA gene } & \multirow[t]{2}{*}{140} & \multirow{2}{*}{$\begin{array}{l}94^{\circ} \mathrm{C} \text { for } 3 \mathrm{~min} ; 35 \text { cycles at } 94^{\circ} \mathrm{C} \\
\text { for } 60 \mathrm{~s}, 54^{\circ} \mathrm{C} \text { for } 60 \mathrm{~s} \text {, and } 72^{\circ} \mathrm{C} \\
\text { for } 2 \mathrm{~min}\end{array}$} & \multirow[t]{2}{*}{22} \\
\hline VMSP2 & AAGGGTACTCAAACGGTCAG & & & & \\
\hline VertBt-F & AACAACAGTCCGATGGATAATTC & \multirow[t]{2}{*}{$\beta$-tubulin gene } & \multirow[t]{2}{*}{115} & \multirow{2}{*}{$\begin{array}{l}3 \mathrm{~min} \text { at } 95^{\circ} \mathrm{C} ; 40 \text { cycles of } 95^{\circ} \mathrm{C} \\
\text { for } 10 \mathrm{~s} \text { and } 63^{\circ} \mathrm{C} \text { for } 35 \mathrm{~s}\end{array}$} & \multirow[t]{2}{*}{4} \\
\hline VertBt-R & GTACCGGGCTCGAGATCG & & & & \\
\hline VDS1 & CACATTCAGTTCAGGAGACGGA & \multirow[t]{2}{*}{ DNA probe sequence } & \multirow[t]{2}{*}{520} & \multirow{2}{*}{$\begin{array}{l}95^{\circ} \mathrm{C} \text { for } 2 \mathrm{~min} ; 40 \text { cycles at } 95^{\circ} \mathrm{C} \\
\text { for } 30 \mathrm{~s}, 62^{\circ} \mathrm{C} \text { for } 30 \mathrm{~s}, 72^{\circ} \mathrm{C} \\
\text { for } 1 \mathrm{~min}, \text { and } 72^{\circ} \mathrm{C} \text { for } 5 \mathrm{~min}\end{array}$} & \multirow[t]{2}{*}{15} \\
\hline VDS2 & CCGAAATACTCCAGTAGAAGG & & & & \\
\hline DB19 & CGGTGACATAATACTGAGA & \multirow[t]{3}{*}{ SCAR sequence $^{\mathrm{a}}$} & \multirow[t]{3}{*}{540} & \multirow{3}{*}{$\begin{array}{l}94^{\circ} \mathrm{C} \text { for } 4 \mathrm{~min} ; 35 \text { cycles of } 1 \mathrm{~min} \\
\text { at } 62^{\circ} \mathrm{C}, 30 \mathrm{~s} \text { at } 72^{\circ} \mathrm{C}, 1 \mathrm{~min} \text { at } 94^{\circ} \mathrm{C}, \\
\text { and } 6 \mathrm{~min} \text { at } 72^{\circ} \mathrm{C}\end{array}$} & \multirow[t]{3}{*}{23} \\
\hline DB22 & GACGATGCGGATTGAACGAA & & & & \\
\hline Espdf01 & $\begin{array}{l}\text { [FAM]TGAGACTCGGCTGCCACAC } \\
\text { [BHQ_1] }\end{array}$ & & & & \\
\hline Vd-F929-947 & CGTTTCCCGTTACTCTTCT & \multirow[t]{3}{*}{ Intragenic spacer } & \multirow[t]{3}{*}{121} & \multirow{3}{*}{$\begin{array}{l}95^{\circ} \mathrm{C} \text { for } 2 \mathrm{~min} ; 55 \text { cycles at } 95^{\circ} \mathrm{C} \\
\text { for } 15 \mathrm{~s} \text { and } 62^{\circ} \mathrm{C} \text { for } 30 \mathrm{~s} .\end{array}$} & \multirow[t]{3}{*}{7} \\
\hline Vd-R1076-1094 & GGATTTCGGCCCAGAAACT & & & & \\
\hline V. dahliae probe & $\begin{array}{l}\text { [FAM]CACCGCAAGCAGACTCTTGA } \\
\text { AAGCCA [BHQ_1] }\end{array}$ & & & & \\
\hline VTP1-2F & CTCGATCGTCGTCAACC & \multirow{3}{*}{$\begin{array}{l}\text { Trypsin protease } \\
\text { (VTP1) gene }\end{array}$} & \multirow[t]{3}{*}{155} & \multirow{3}{*}{$\begin{array}{l}2 \mathrm{~min} \text { at } 95^{\circ} \mathrm{C} ; 40 \text { cycles of } 30 \mathrm{~s} \\
\text { at } 95^{\circ} \mathrm{C}, 60 \mathrm{~s} \text { at } 58^{\circ} \mathrm{C} \text {, and } 30 \mathrm{~s} \text { at } 72^{\circ} \mathrm{C}\end{array}$} & \multirow[t]{3}{*}{27} \\
\hline VTP1-2R & TGGTGGTGAGAGTGTTG & & & & \\
\hline VTP1-2P & $\begin{array}{l}\text { [FAM]TACGACAACGACTTCGCCATC } \\
\text { [BHQ_1] }\end{array}$ & & & & \\
\hline
\end{tabular}

\footnotetext{
a Sequence-characterized amplified region (SCAR) from V. dahliae.
} 
exhibited melt temperatures of approximately $79^{\circ} \mathrm{C}$, typical of primerdimers and short, nonspecific amplification products (Fig. 1). Moreover, using gel electrophoresis, the primer pair VertBt amplified a unique DNA fragment of the expected size of approximately $115 \mathrm{bp}$ from the DNA extracts of all $V$. dahliae isolates, and no amplicon was observed with the isolates of V. albo-atrum, P. capsici, and P. oryzae (Supplementary Fig. S1). Results of using this primer set were consistent over two experiments, and the entire amplification time was about $50 \mathrm{~min}$, which is the shortest among all primer sets tested.

The SYBR Green-based assay using the VDS primers amplified all isolates of $V$. dahliae with $\mathrm{C}_{\mathrm{t}}$ values of 23 to 28; $V$. albo-atrum and negative controls were amplified with $C_{t}$ values of 32 to 33 . However, the specificity of VDS primers was indicated by the melt temperatures, which were between 87 and $88^{\circ} \mathrm{C}$ for all isolates of $V$. dahliae and between 77 and $76^{\circ} \mathrm{C}$ for the $V$. albo-atrum isolate plus the negative controls (Fig. 2). VDS primers produced the expected DNA fragment of approximately $541 \mathrm{bp}$ from the DNA extracts of all $\mathrm{V}$. dahliae isolates over two experiments (Supplementary Fig. S2). DNA extracts of V. albo-atrum, Phytophthora capsici (Supplementary Fig. S2), and Pyricularia oryzae (data not shown) yielded no amplicon.

The VSMP primers amplified a DNA fragment of about $140 \mathrm{bp}$, the expected size for the amplicon from this primer set, but one $V$. dahliae isolate (number 64114) consistently produced a double band (Supplementary Fig. S3). However, these primers did not amplify the isolates of V. albo-atrum, Phytophthora capsici (Supplementary Fig. S3), or Pyricularia oryzae (data not shown). Primers DB19 and DB22 consistently produced an amplicon of the expected size in some isolates of $V$. dahliae but not in others (Supplementary Fig. S4). The remaining primer sets tested (Vd-F929-947/Vd-R1076-re and primers VTP12F/VTP1-2R, each set with its corresponding Taqman probe) failed to amplify the expected DNA fragment from the DNA extracts of all $V$. dahliae isolates tested (data not shown).

Real-time PCR sensitivity. Using the VertBt primers, the relationship between the $C_{t}$ value and template concentration was nearly linear over the range of concentrations of $20 \mathrm{ng}$ to $20 \mathrm{pg}$ per reaction (Fig. 3), with a calculated real-time PCR efficiency of $E=0.99$ over this range. The minimum quantity of $V$. dahliae DNA that could be detected with this primer set was 2 pg per reaction. Using the VDS primers, $C_{t}$ values were nearly linear over a range of template concentrations of $20 \mathrm{ng}$ to $2 \mathrm{pg}$. In other words, the real-time PCR protocol using VDS primer set detected about five $V$. dahliae genome equivalents (which would be the DNA expected from approximately five cells of $V$. dahliae) per 25- $\mu 1$ reaction (Fig. 4). For the VDS primers, the detection limit was $0.2 \mathrm{pg}$ of $V$. dahliae DNA per reaction. With either primer set, the presence of host DNA (maple) did not influence the real-time PCR efficiency, as indicated by the similarity of $\mathrm{C}_{\mathrm{t}}$ values over a wide range of template concentrations (Figs. 3 and 4).

Disruption of woody tissue and its impact on DNA extraction. Primary tissue disruption using a drill bit followed by processing with a bead beater provided the highest DNA concentration with oven-dried twigs from ash trees, especially when compared with yield using the pencil sharpener (Fig. 5A). In oven-dried maple twigs, the drill bit followed by the bead beater exhibited the highest numerical mean of DNA concentration compared with other treatments but it also exhibited high variability as reflected in the high standard error values (Fig. 5B). In fresh ash twigs, the highest concentration of DNA numerically was provided by the pencil sharpener followed by drill press with mesh bags, although variability was also high in that treatment (Fig. 5C). In contrast, in fresh maple twigs, the drill bit followed by the drill press with mesh bags provided the highest DNA concentration (Fig. 5D). Using the primary

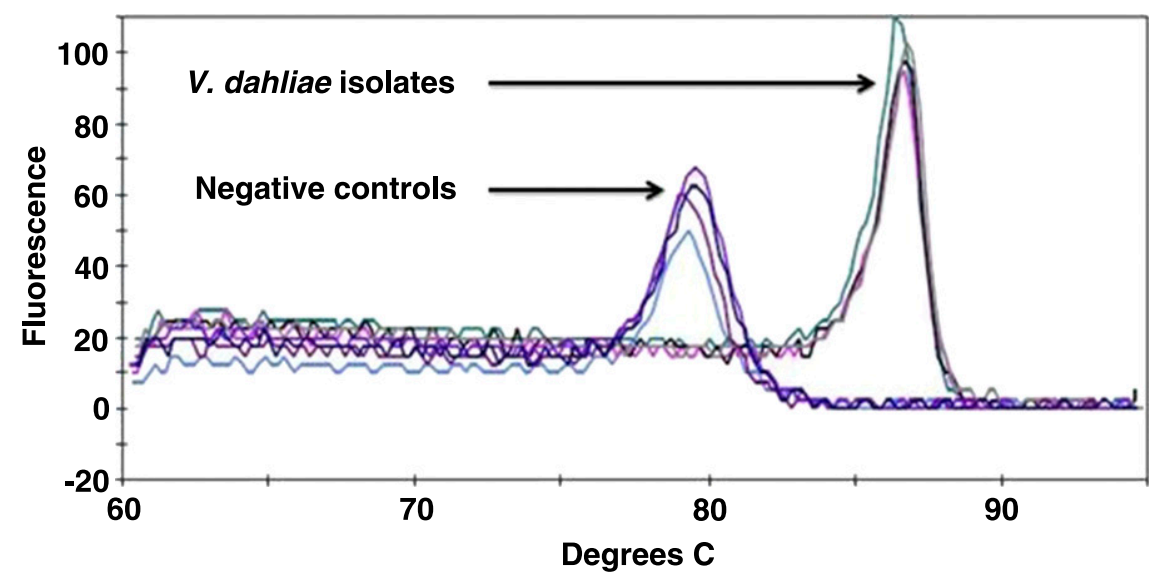

Fig. 1. Melt derivative curves generated from polymerase chain reaction amplicons in a SYBR Green-based assay using VertBt primer set for detecting Verticillium dahliae.

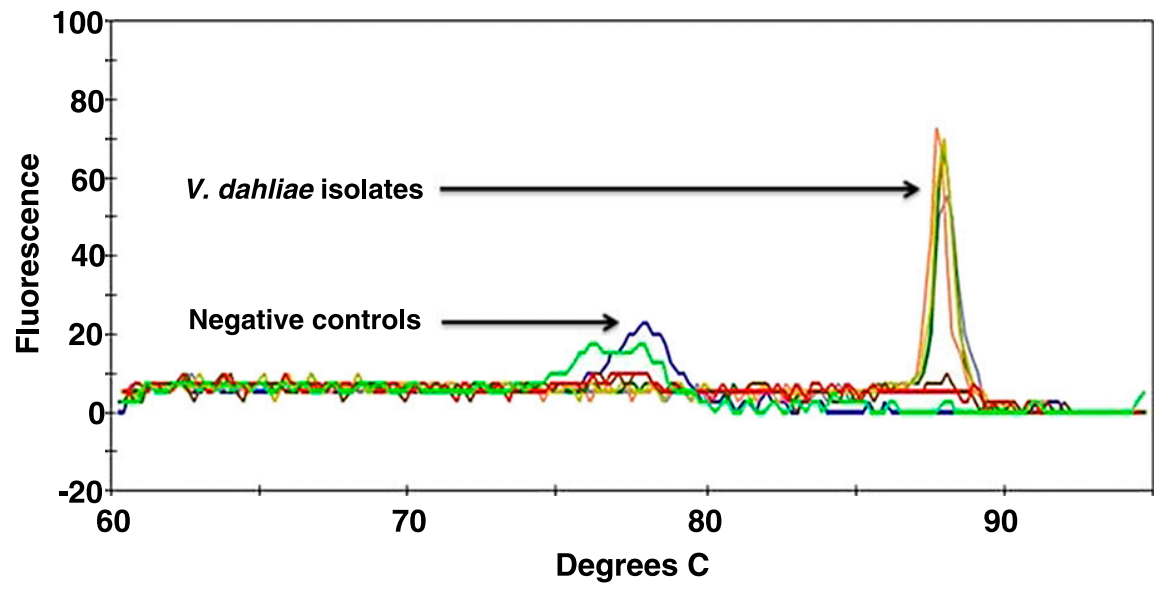

Fig. 2. Melt derivative curves generated from polymerase chain reaction amplicons in a SYBR Green-based assay using the VDS primer set for detecting Verticillium dahlia. 
tissue disruption only (by either the mechanical pencil sharpener or drill bit), with no secondary tissue disruption, was consistently associated with low DNA yield (Fig. 5A to D), likely due to inadequate mechanical disruption.

Evaluation for real-time PCR inhibition in DNA extracts from woody tissues. In this study, two real-time PCR-based assays (based on VertBt and VDS primer sets) showed promise for detection of $V$. dahliae in woody hosts. Amplification of the $V$. dahliae $\beta$-tubulin gene target using the VertBt primers was generally not influenced by the presence of DNA extracts from a variety of woody plants, as reflected in $C_{t}$ values similar to that of the positive control (Fig. 6). One woody species (crabapple) exhibited a detection threshold $\mathrm{C}_{\mathrm{t}}$ value slightly higher than the positive control but an increase in the $\mathrm{C}_{\mathrm{t}}$ value of approximately 0.6 cycles compared with the control is not considered to be reflective of substantial reaction inhibition. Real-time PCR using the VDS primers was similarly unaffected by the same DNA extracts obtained from woody species, with the exception of the extract from redbud (Fig. 7). However, that observed increase in $\mathrm{C}_{\mathrm{t}}$ value was also modest and unlikely to impede detection in infected trees. These results suggest that amplification using the VertBt and VDS primers may often be unaffected by the PCR inhibitors in DNA extracts obtained from woody plants.

Application of selected real-time PCR assays to field-grown trees. Using the VertBt primer set, seven of eight twigs sampled from asymptomatic tree number one exhibited a positive reaction, as did all eight twigs sampled from asymptomatic tree number two (Table 3). All twigs sampled from maples exhibiting wilt symptoms but no vascular discoloration also were positive, using VertBt primers. In addition, all eight twigs sampled from a smoke tree exhibiting wilt symptoms plus vascular discoloration were PCR-positive using the VertBt primer set, while seven of eight twigs were PCR-positive in the second smoke tree. In addition, none of the samples exhibited PCR inhibition using the VertBt primer set, as indicated by similar $\mathrm{C}_{\mathrm{t}}$ values obtained using $V$. dahliae 876 in the presence or the absence of sample DNA extract (data not shown). In contrast, the real-time PCR-based assay with the VDS primer set produced negative results using the same DNA extracts (Table 3); as with VertBt primers, there was no evidence of PCR inhibition caused by DNA extracts from these woody samples in real-time PCR reactions containing DNA of $V$. dahliae 876 (data not shown). In each sample where culturing was performed, colonies typical of $V$. dahliae were obtained (Table 3), verifying infection by $V$. dahliae.

Both primer sets were also tested with samples of a variety of woody hosts exhibiting varied symptoms typical of Verticillium wilt and submitted by University of Kentucky Extension agents (Table 4). Sample number 1197, obtained from a smoke tree with classic symptoms of Verticillium wilt, exhibited a positive result with the VertBt primer set but a negative result with the VDS primers. In that case, complete PCR inhibition of the VDS primers was detected in the reaction of $V$. dahliae 884 spiked with sample DNA extract. Negative results were observed with both primer sets with samples 1615, P-750, and 1869

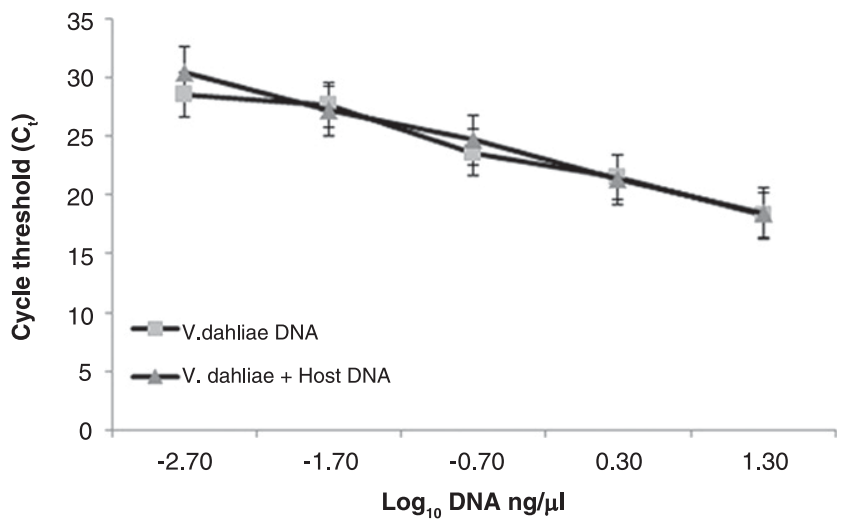

Fig. 3. Real-time quantitative polymerase chain reaction efficiency curves using primers VertBt-F/NertBt-R and serially diluted genomic DNA of Verticillium dahliae (isolate 884) in either the presence or the absence of $2 \mathrm{ng}$ of total sample DNA extracted from an uninfected maple tree. Bars indicate standard errors. sampled from a variety of woody plants exhibiting both wilt and vascular discoloration symptoms. Also, the culture plating supported the negative results of these samples. In addition, sample Vincelli was negative using both primer sets, and the culture plating provided no evidence of the presence the pathogen in this sample. In that case, the tree exhibited foliar wilt, rapidly progressing truck cankers, and associated discoloration of the cambium, consistent with a canker disease and not Verticillium wilt; thus, negative real-time PCR tests were consistent with field observations. Maple sample P-781 exhibited wilt symptoms but not vascular discoloration symptoms and gave a positive result with the VertBt primer set and a negative result with the VDS primer set. Furthermore, $V$. dahliae was isolated successfully from the maple sample P-781 using the culture plating method, corroborating the real-time PCR results obtained with the VertBt primers. Redbud sample 1570 exhibited both classic foliar wilt and vascular discoloration symptoms, and gave a positive PCR result using both primer sets. However, isolation of the pathogen from this sample was unsuccessful. Sugar maple sample 2188 exhibited classic wilt symptoms but not vascular discoloration yet tested positive with both primer sets, and $V$. dahliae was isolated successfully using the culture plating method.

For confirmation of the amplicons observed, the amplicon obtained using the VDS primers on two PCR-positive woody host samples was confirmed via direct sequencing. The sequences generated from positive samples exhibited $100 \%$ identity against accessions of $V$. dahliae, based on an NCBI BLAST search. The amplicon generated using the VertBt primer set was too small to direct sequence; therefore, restriction digestion (HaeIII) was used to verify amplicon identity. In all six samples tested, digestion of amplicons obtained using the VertBt primers produced fragments of the expected size (data not shown).

\section{Discussion}

This study presents a detection tool for $V$. dahliae in woody hosts using real-time PCR based on the VertBt primer set, generated from the single-copy $\beta$-tubulin gene of $V$. dahliae (4). Also, another real-time PCR-based assay for detection $V$. dahliae in woody hosts was evaluated using the VDS primer set, designed from a specific probe sequence of $V$. dahliae (24). However, the VDS primers failed to amplify from several asymptomatic or symptomatic infected woody hosts. Moreover, this primer set was sensitive to PCR inhibition with a sample from a fieldgrown smoke tree, which may sometimes cause false-negative reactions. The VSMP primers successfully amplified a single band of the expected size from several isolates of $V$. dahliae. However, they consistently amplified double bands from isolate 64114 of $V$. dahliae, which could be due to several reasons. One is that, although this study used the annealing temperature indicated in the original description $\left(54^{\circ} \mathrm{C}\right)$, it may have been lower than optimal, which would increase the chance for primer binding to nonspecific targets. Alternatively, it is possible that primer concentration was excessive, which may increase primer binding to nonspecific targets as well. Given that these primers amplify repetitive gene sequences, there is also the possibility that fragments of different

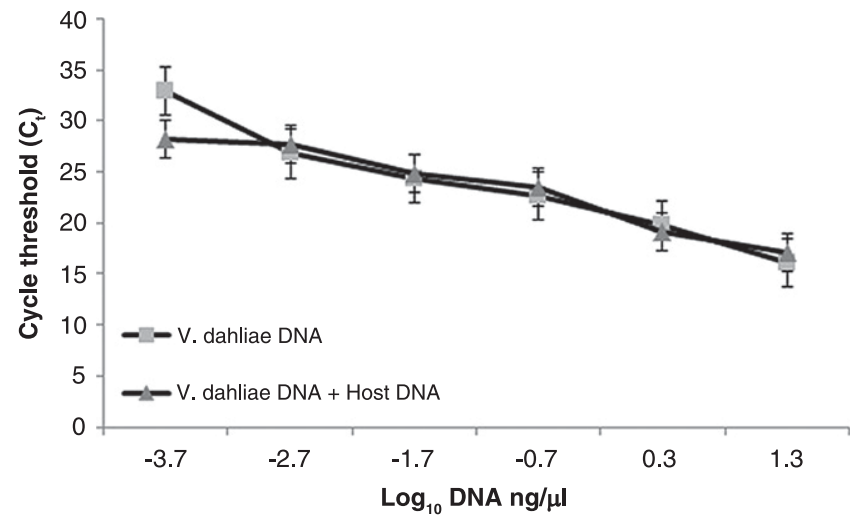

Fig. 4. Real-time quantitative polymerase chain reaction efficiency curves using primers VDS1NDS2 and serially diluted genomic DNA of Verticillium dahliae (isolate 884) in either the presence or the absence of $2 \mathrm{ng}$ of total sample DNA extracted from an uninfected maple tree. Bars indicate standard errors. 
lengths exist in the intervening sequences between the primer-binding sites, which would result in bands of different sizes. The DB primer set amplified some but not all isolates of $V$. dahliae tested, which suggests that this primer set is not reliable as a diagnostic tool for Verticillium wilt in woody hosts. Because the remaining primer sets failed to amplify DNA extracts obtained from isolates of $V$. dahliae, they clearly are not suitable for diagnosis, at least under the test conditions of this study.

Several studies have used PCR-based methods for diagnosis of several tree-infecting fungal species, and such assays should demonstrate a high level of sensitivity and specificity in order to be a successful method for pathogen detection $(8,9,17,29,31)$. The real-time PCR-based method presented here, using the VertBt primer set, detected as little as $2 \mathrm{pg}$ of genomic DNA of $V$. dahliae in either the presence or the absence of host DNA. In addition to demonstrating a high level of sensitivity, this provides additional evidence that the VertBt primers are generally insensitive to PCR inhibitors of woody hosts, or that our technique for extracting DNA from woody hosts results in minimal amounts of inhibitory substances. Furthermore, this set of primers was able to detect the presence of $V$. dahliae in woody samples even before the host exhibited symptoms.

Several techniques have been used to detect $V$. dahliae in a variety of hosts. These include culturing on a selective medium, a technique which presents certain difficulties, including being time-consuming, the limited number of samples that can be processed, and labor requirements (30). Furthermore, selective media lack specificity due to the slow growth of $V$. dahliae, which can be overrun by growth of other microorganisms such as fungi and bacteria $(18,30)$. Because of the lack of a rapid, sensitive, and specific method to detect $V$. dahliae in woody hosts, this rapid and reliable diagnostic tool for detection of $V$. dahliae in woody hosts will be useful.

In the present study, a new two-step procedure was developed to disrupt the hard xylem of woody plant tissues for DNA extraction.
In primary tissue disruption, a drill bit was effective in creating small wood shavings from small twigs and branches as a first step in tissue processing. Using the drill bit for primary tissue disruption followed by the bead beater for secondary tissue disruption yielded high DNA concentrations from oven-dried twigs of both ash and maple. In contrast, in fresh tissues, a pencil sharpener for primary tissue disruption followed by the drill press with mesh bags yielded the highest DNA concentration from ash twigs. However, this treatment exhibited high

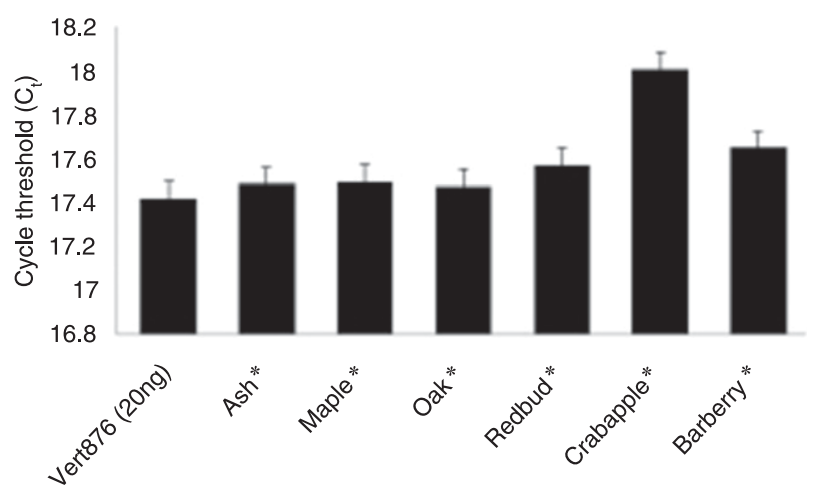

* DNA of the host spiked with $20 \mathrm{ng}$ of $V$. dahliae

Fig. 6. Effects of the presence of DNA extract from various woody species on real-time polymerase chain reaction (PCR) using VertBt-F/NertBt-R primers for detection of Verticillium dahliae. All PCR reactions received $20 \mathrm{ng}$ of extract of genomic DNA of $V$. dahliae isolate 876 . Tubes marked with a plant name also received $20 \mathrm{ng}$ of DNA extract obtain from asymptomatic, PCR-negative trees. Bars indicate standard errors.
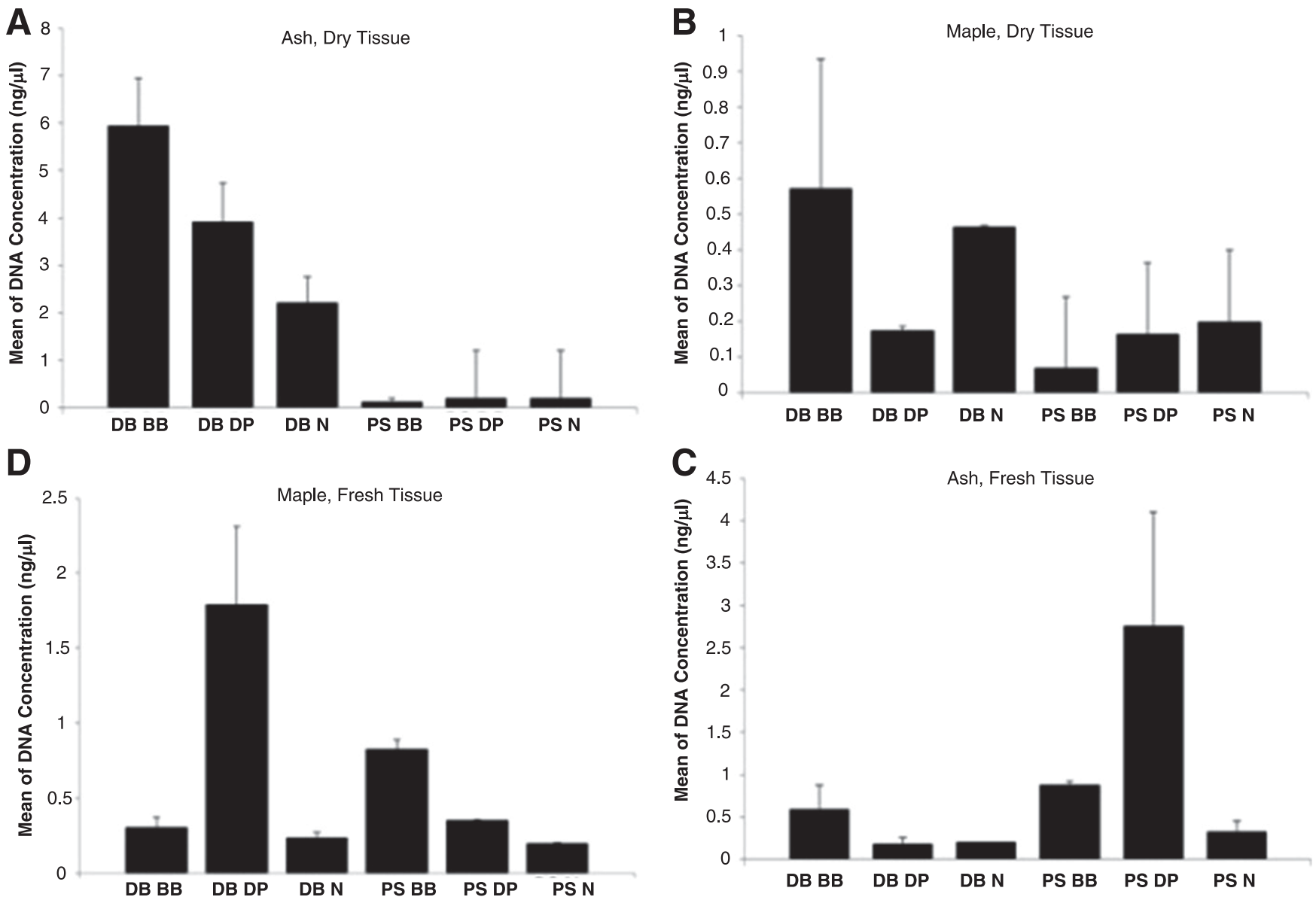

Fig. 5. DNA yields from oven-dried and fresh sample twigs processed by different methods of primary tissue disruption followed by secondary tissue disruption. Primary tissue disruption methods: $\mathrm{DB}=$ drill bit and $\mathrm{PS}=$ pencil sharpener. Secondary tissue disruption methods: $\mathrm{BB}=$ bead beater, $\mathrm{DP}=$ drill press with mesh bags, and $\mathrm{N}=\mathrm{no}$ secondary tissue disruption method. Bars indicate standard errors. 
variability, as reflected in high standard error values. With fresh maple twigs, the highest DNA concentration was obtained using a drill bit for primary tissue disruption followed by the drill press with mesh bags. In other words, both experimental factors-host species and condition (dried versus fresh) — influenced the DNA yield from samples of woody plants. Furthermore, woody tissues often have high concentrations of phenolic compounds and polysaccharides, which may be inhibitory to enzymes used in real-time PCR. However, the drill bit followed by bead-beating and CTAB extraction presented here seems effective in minimizing or eliminating PCR inhibitors. Furthermore, both real-time PCR assays, especially the one based on

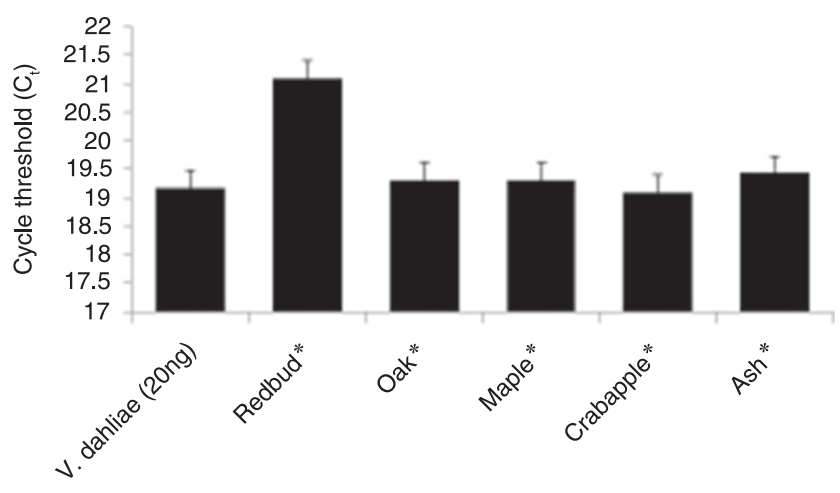

*DNA of the host spiked with 20 ng of $V$. dahliae DNA

Fig. 7. Effect of the presence of DNA extract from various woody species on real-time polymerase chain reaction (PCR) using VDS primers for detection of Verticillium dahliae. All PCR reactions received $20 \mathrm{ng}$ of extract of genomic DNA of $V$. dahliae isolate 876 . Tubes marked with a plant name also received $20 \mathrm{ng}$ of DNA extract obtain from asymptomatic, PCR-negative trees. Bars indicate standard errors. the VertBt primer set, were able to detect DNA of $V$. dahliae extracted from infected woody hosts, which suggests that the extracted DNA contained insignificant amounts of compounds that could inhibit the realtime PCR reaction. In the inhibition test with DNA extracts from a variety of woody plant species, we spiked the extracts with $20 \mathrm{ng}$ of $V$. dahliae, which would be equivalent to $5.4 \times 10^{5}$ target molecules per real-time PCR reaction. The high concentration of $V$. dahliae genome equivalents used in these tests could potentially overcome the influence of the PCR inhibitors in woody samples in the real-time PCR reaction. Thus, one cannot rule out the possibility that higher levels of inhibition might occur if substantially lower concentrations of genomic DNA of $V$. dahliae were used in the presence of the same amount of host extract.

In conclusion, a powerful, rapid, and reliable molecular tool based on published primers was developed for detection of $V$. dahliae in woody hosts. A real-time PCR-based assay using the VertBt primer set exhibited greater accuracy and sensitivity than real-time PCR-based methods employing five other published primer sets, and was much faster than traditional microbiological isolation procedures. This molecular tool has many applications which could be useful in plant disease diagnosis and management, especially because the most practical and economical control method for $V$. dahliae in woody hosts is avoiding planting infected transplants in newly established nurseries or landscapes (18). The real-time PCR-based assay using the VertBt primer set could potentially be used in screening for the presence of $V$. dahliae in nurseries or in mother trees, which could be valuable in maintaining sanitation during the establishment of new plantings. It was notable that this primer set was able to detect the presence of $V$. dahliae in infected asymptomatic woody samples, suggesting that this method would be able to detect the pathogen at an early stage of infection. In addition, this study showed that the time needed to diagnose $V$. dahliae in woody hosts can be reduced from several days (required for culture-based methods) to 1 day, which allows time for both DNA extraction and real-time PCR using the VertBt primer set.

Table 3. Comparison of real-time polymerase chain reaction (PCR)-based assay with VertBt primers and VDS primers, and culture plating for detection of Verticillium dahliae in trees exhibiting differing symptom types, including asymptomatic sugar maple (AST), sugar maple exhibiting wilt symptoms (WST), and a smoke tree exhibiting wilt plus vascular discoloration (VST)

\begin{tabular}{llccc}
\hline & & \multicolumn{2}{c}{ Real-time PCR result $^{\mathbf{a}}$} & \\
\cline { 3 - 4 } Tree symbol $^{\mathbf{b}}$ & \multicolumn{1}{c}{ Tree status } & VertBt primers & VDS primers & Culture plating on 1.5\% water agar $^{\mathbf{c}}$ \\
\hline AST1 & Asymptomatic & $7 / 8$ & $0 / 8$ & $2 / 2$ \\
AST2 & Asymptomatic & $8 / 8$ & $0 / 8$ & $\mathrm{NT}$ \\
WST1 & Wilt symptoms & $8 / 8$ & $0 / 8$ & $2 / 2$ \\
WST2 & Wilt symptoms & $8 / 8$ & $0 / 8$ & $\mathrm{NT}$ \\
VST1 & Vascular symptoms & $8 / 8$ & $0 / 8$ & $2 / 2$ \\
VST2 & Vascular symptoms & $7 / 8$ & $0 / 8$ & $\mathrm{NT}$ \\
\hline
\end{tabular}

a Number of positive twigs/total number of twigs sampled from the same tree.

b Number indicates the tree number sampled within that symptom category.

c Of two twigs tested to verify the presence of $V$. dahliae by culturing and morphological examination, "2/2" indicates two twigs positive and "NT" indicates not tested (culturing not attempted on twigs from this tree).

Table 4. Polymerase chain reaction (PCR) results of samples of woody hosts collected in Kentucky and submitted for diagnosis due to suspicion of Verticillium dahliae

\begin{tabular}{|c|c|c|c|c|c|c|c|}
\hline \multirow[b]{2}{*}{ Number of samples } & \multirow[b]{2}{*}{ Host } & \multirow[b]{2}{*}{ Location } & \multirow[b]{2}{*}{ Wilt symptoms $^{b}$} & \multirow[b]{2}{*}{ Vascular discoloration ${ }^{c}$} & \multicolumn{2}{|c|}{ Real-time PCR resultsa } & \multirow[b]{2}{*}{ Culture plating } \\
\hline & & & & & VertBt primers & VDS primers & \\
\hline 1197 & Smoke tree & Nelson County & + & + & + & - & NT \\
\hline 1615 & Catalpa & Bath County & + & + & - & - & - \\
\hline 2232 & Smoke tree & Frankfort & + & + & + & - & + \\
\hline P-750 & Barberry & McCracken County & + & + & - & - & - \\
\hline P-781 & Maple & Christian County & + & - & + & - & + \\
\hline 2188 & Sugar maple & Fayette County & + & - & + & + & + \\
\hline 1869 & Norway maple & Oldham County & + & + & - & - & - \\
\hline 1570 & Redbud & Fayette County & + & + & + & + & - \\
\hline Vincelli & Redbud & Fayette County & + & + & - & - & - \\
\hline
\end{tabular}

a Symbols + and - indicate positive and negative results, respectively, with real-time PCR.

b Symbols + and - indicate twigs sampled from a tree exhibiting wilt symptoms or exhibiting no wilt symptoms, respectively.

c Symbols + and - indicate twigs sampled from tree exhibiting vascular discoloration or exhibiting no vascular discoloration, respectively.

d Cultures made on water agar. NT indicates not tested. 
For future research on this topic, evaluation of the VertBt primer set using more isolates of $V$. dahliae would be valuable in order to represent potentially different clades of $V$. dahliae and different geographical areas and isolates of different host origin. It may be beneficial to evaluate these real-time PCR-based assays with a wide variety of isolates of $V$. dahliae, in order to evaluate the primer sets against the widest possible range of genetic variability in the target genome regions among $V$. dahliae isolates that infect woody hosts.

\section{Acknowledgments}

We thank B. Amsden and E. Dixon for their technical assistance, and K. Subbarao (University of California) for providing all of the Verticillium isolates used in this study.

\section{Literature Cited}

1. Aljawasim, B. D. G. 2014. Evaluation of PCR-based methods for rapid, accurate delectation and monitoring of Verticillium dahliae in woody hosts by real-time polymerase chain reaction. Online publication. Theses and Dissertations-Plant Pathology, Paper 13. http://uknowledge.uky.edu/plantpath_etds/13

2. Ash, C. L. 1993. Verticillium Wilt of Trees and Shrubs. Online publication. Univ. Minn. Ext. Serv. http://www.extension.umn.edu/garden/yard-garden/ trees-shrubs/verticillium-wilt/

3. Ash, C. L. 1999. The Ecology of Verticillium dahliae in Fraxinus and Acer Species. Ph.D. dissertation, University of Minnesota, St. Paul.

4. Atallah, Z. K., Bae, J., and Jansky, S. H. 2007. Multiplex real-time quantitative PCR to detect and quantify Verticillium dahliae colonization in potato lines that differ in response to Verticillium wilt. Phytopathology 97:865-872.

5. Ausher, R., Katan, J., and Ovadio, S. 1975. An improved selective medium for the isolation of Verticillium dahliae. Phytoparasitica 3:133-137.

6. Bessetti, J. 2007. An introduction to PCR inhibitors. J. Microbiol. Methods 28: 159-167.

7. Bilodeau, G. J., and Koike, S. T. 2012. Development of an assay for rapid detection and quantification of Verticillium dahliae in soil. Phytopathology 102:331-343

8. Broders, K. D. 2010. Molecular diagnostic assay for detection of the butternut canker pathogen Sirococcus clavigignenti-juglandacearum. Plant Dis. 94: 952-958.

9. Cho, M. S., Kang, M. J., and Kim, C. K. 2011. Sensitive and specific detection of Xanthomonas oryzae pv. oryzae by real-time bio-PCR using pathovarspecific primers based on an rhs family gene. Plant Dis. 95:589-594.

10. Dan, H., Ali-Khan, S. T., and Robb, J. 2001. Use of quantitative PCR diagnostics to identify tolerance and resistance to Verticillium dahliae in potato. Plant Dis. 85:700-705.

11. de Almeida, R. F. 2009. Host transcriptional responses to vascular and foliar phytopathogenic fungi. Online publication. Ph.D. thesis, Universidade Federal de Viçosa, Minas Gerais, Brasil. http://www.sbicafe.ufv.br/bitstream/handle/ 10820/3296/226155f.pdf?sequence=1

12. Debode, J., Van Poucke, K., França, S. C., Maes, M., Höfte, M., and Heungens, K. 2011. Detection of multiple Verticillium species in soil using density flotation and real-time polymerase chain reaction. Plant Dis. 95: 1571-1580.

13. Demeke, T., and Adams, R. P. 1992. The effects of plant polysaccharides and buffer additives on PCR. Biotechniques 12:332-334.

14. Duressa, D., Rauscher, G., and Koike, S. T. 2012. A real-time PCR assay for detection and quantification of Verticillium dahliae in spinach seed. Phytopathology 102:443-451.
15. Gayoso, C., de la Ilarduya, O. M., and Pomar, F. 2007. Assessment of realtime PCR as a method for determining the presence of Verticillium dahliae in different Solanaceae cultivars. Eur. J. Plant Pathol. 118:199-209.

16. Green, M. J., Thompson, D. A., and MacKenzie, D. J. 1999. Easy and efficient DNA extraction from woody plants for the detection of phytoplasmas by polymerase chain reaction. Plant Dis. 83:482-485.

17. Hamelin, R. C., Bourassa, M., Rail, J., Dusabenyagasani, M., Jacobi, V., and Laflamme, G. 2000. PCR detection of Gremmeniella abietina, the causal agent of Scleroderris canker of pine. Mycol. Res. 104:527-532.

18. Karajeh, M. R., and Masoud, S. A. 2006. Molecular detection of Verticillium dahliae Kleb. in asymptomatic olive trees. J. Phytopathol. 154:496-499.

19. Li, K. N., Rouse, D. I., and German, T. L. 1994. PCR primers that allow intergeneric differentiation of ascomycetes and their application to Verticillium spp. Appl. Environ. Microbiol. 60:4324-4331.

20. Li, R., Mock, R., Huang, Q., Abad, J., Hartung, J., and Kinard, G. 2008. A reliable and inexpensive method of nucleic acid extraction for the PCRbased detection of diverse plant pathogens. J. Virol. Methods 154:48-55.

21. Martin, R. R., James, D., and Levesque, C. A. 2000. Impacts of molecular diagnostic technologies on plant disease management. Annu. Rev. Phytopathol. 38:207-239.

22. Mascarello, N., Favaron, F., and Di Lenna, P. 2001. Evaluation of a PCRbased method to detect Verticillium dahliae in chicory taproots. J. Plant Pathol. 83:221-224.

23. McCartney, H. A., Foster, S. J., Fraaije, B. A., and Ward, E. 2003. Molecular diagnostics for fungal plant pathogens. Pest Manag. Sci. 59:129-142.

24. Mercado-Blanco, J., Rodriguez-Jurado, D., Parrilla-Araujo, S., and JimenezDiaz, R. M. 2003. Simultaneous detection of the defoliating and nondefoliating Verticillium dahliae pathotypes in infected olive plants by duplex, nested polymerase chain reaction. Plant Dis. 87:1487-1494.

25. Mumford, R. A., Walsh, K., Barker, I, and Boonham, N. 2000. Detection of potato mop top virus and tobacco rattle virus using a multiplex real-time fluorescent reverse-transcription polymerase chain reaction assay. Phytopathology 90:448-453.

26. Osman, F., and Rowhani, A. 2006. Application of a spotting sample preparation technique for the detection of pathogens in woody plants by RT-PCR and realtime PCR (TaqMan). J. Virol. Methods 133:130-136.

27. Pasche, J. S., Thompson, A. L., and Gudmestad, N. C. 2013. Quantification of field resistance to Verticillium dahliae in eight russet-skinned potato cultivars using real-time PCR. Am. J. Potato Res. 90:158-170.

28. Pernezny, K., Roberts, P. D., Murphy, J. F., and Goldberg, N. 2003 Compendium of Pepper Diseases. American Phytopathological Society, St. Paul, MN

29. Piskur, B., Ogris, N., and Jurc, D. 2007. Species-specific primers for Eutypella parasitica, the causal agent of Eutypella canker of maple. Plant Dis. 91:1579-1584.

30. Plasencia, J., and Banttari, E. E. 1997. Comparison between a culture plate method and an immunoassay to evaluate vascular colonization of potato by Verticillium dahliae. Plant Dis. 81:53-56.

31. Ramsfield, T. D., Dobbie, K., Dick, M. A., and Ball, R. D. 2008. Polymerase chain reaction-based detection of Fusarium circinatum, the causal agent of pitch canker disease. Mol. Ecol. Resour. 8:1270-1273.

32. Wang, Y. L., Wang, Y., and Tian, C. M. 2013. Quantitative detection of pathogen DNA of Verticillium wilt on smoke tree Cotinus coggygria. Plant Dis. 97:1645-1651.

33. Zhang, Y. P., Uyemoto, J. K., and Kirkpatrick, B. C. 1998. A small-scale procedure for extracting nucleic acids from woody plants infected with various phytopathogens for PCR assay. J. Virol. Methods 71:45-50.

34. Zheng, G. G., Chen, R. H., Wang, Y. C., Wang, K. R., and Zheng, X. B. 2005 Molecular detection of Verticillium albo-atrum by PCR based on its sequences. Agric. Sci. China 4:760-766

This article was modified on 29 Sep 2015 
ERRATUM / Volume 99, Number 6, 2015 / PDIS-05-14-0528-RE

In the article "Evaluation of Polymerase Chain Reaction (PCR)-Based Methods for Rapid, Accurate Detection and Monitoring of Verticillium dahliae in Woody Hosts by Real-Time PCR" by B. Aljawasim and P. Vincelli, the thermocycling protocol presented in Table 2 for primers Vd-F929-947 and Vd-R1076, with their corresponding Taqman probe, is incorrect. The correct conditions are shown in the table here. Under these conditions, this primer/probe set provided amplification of our $V$. dahliae isolates in five of ten experiments in our hands. Further experimentation with this primer/probe set against isolates of $V$. dahliae from woody hosts, using with originally published thermocycling conditions, seems desirable.

Table 2. Primer name, sequences, molecular target, fragment length, and citation of all specific primers and probes for Verticillium dahliae evaluated in this study

\begin{tabular}{|c|c|c|c|c|c|}
\hline Oligo name & Oligo sequence $\left(5^{\prime}-3^{\prime}\right)$ & Target & $\begin{array}{c}\text { Fragment } \\
\text { length (bp) }\end{array}$ & Thermocycling conditions & Citation \\
\hline VMSP1 & CATAAAAGACTGCCTACGCCG & \multirow[t]{2}{*}{ rDNA gene } & \multirow[t]{2}{*}{140} & \multirow{2}{*}{$\begin{array}{l}94^{\circ} \mathrm{C} \text { for } 3 \mathrm{~min} ; 35 \text { cycles at } 94^{\circ} \mathrm{C} \\
\text { for } 60 \mathrm{~s}, 54^{\circ} \mathrm{C} \text { for } 60 \mathrm{~s} \text {, and } 72^{\circ} \mathrm{C} \\
\text { for } 2 \mathrm{~min}\end{array}$} & \multirow[t]{2}{*}{22} \\
\hline VMSP2 & AAGGGTACTCAAACGGTCAG & & & & \\
\hline VertBt-F & AACAACAGTCCGATGGATAATTC & \multirow[t]{2}{*}{$\beta$-tubulin gene } & \multirow[t]{2}{*}{115} & \multirow{2}{*}{$\begin{array}{l}3 \mathrm{~min} \text { at } 95^{\circ} \mathrm{C} ; 40 \text { cycles of } 95^{\circ} \mathrm{C} \\
\text { for } 10 \mathrm{~s} \text { and } 63^{\circ} \mathrm{C} \text { for } 35 \mathrm{~s}\end{array}$} & \multirow{2}{*}{4} \\
\hline VertBt-R & GTACCGGGCTCGAGATCG & & & & \\
\hline VDS1 & CACATTCAGTTCAGGAGACGGA & \multirow[t]{2}{*}{ DNA probe sequence } & \multirow[t]{2}{*}{520} & \multirow{2}{*}{$\begin{array}{l}95^{\circ} \mathrm{C} \text { for } 2 \mathrm{~min} ; 40 \text { cycles at } 95^{\circ} \mathrm{C} \\
\text { for } 30 \mathrm{~s}, 62^{\circ} \mathrm{C} \text { for } 30 \mathrm{~s}, 72^{\circ} \mathrm{C} \\
\text { for } 1 \mathrm{~min} \text {, and } 72^{\circ} \mathrm{C} \text { for } 5 \mathrm{~min}\end{array}$} & \multirow[t]{2}{*}{15} \\
\hline VDS2 & CCGAAATACTCCAGTAGAAGG & & & & \\
\hline DB19 & CGGTGACATAATACTGAGA & \multirow[t]{3}{*}{ SCAR sequence ${ }^{a}$} & \multirow[t]{3}{*}{540} & \multirow{3}{*}{$\begin{array}{l}94^{\circ} \mathrm{C} \text { for } 4 \mathrm{~min} ; 35 \text { cycles of } 1 \mathrm{~min} \\
\text { at } 62^{\circ} \mathrm{C}, 30 \mathrm{~s} \text { at } 72^{\circ} \mathrm{C}, 1 \mathrm{~min} \text { at } 94^{\circ} \mathrm{C} \text {, } \\
\text { and } 6 \mathrm{~min} \text { at } 72^{\circ} \mathrm{C}\end{array}$} & \multirow[t]{3}{*}{23} \\
\hline DB22 & GACGATGCGGATTGAACGAA & & & & \\
\hline Espdf01 & $\begin{array}{l}\text { [FAM]TGAGACTCGGCTGCCACAC } \\
\text { [BHQ_1] }\end{array}$ & & & & \\
\hline Vd-F929-947 & CGTTTCCCGTTACTCTTCT & \multirow[t]{3}{*}{ Intragenic spacer } & \multirow[t]{3}{*}{121} & \multirow{3}{*}{$\begin{array}{l}95^{\circ} \mathrm{C} \text { for } 2 \mathrm{~min} ; 55 \text { cycles at } 95^{\circ} \mathrm{C} \\
\text { for } 15 \mathrm{~s} \text { and } 62^{\circ} \mathrm{C} \text { for } 30 \mathrm{~s} .\end{array}$} & \multirow[t]{3}{*}{7} \\
\hline Vd-R1076-1094 & GGATTTCGGCCCAGAAACT & & & & \\
\hline V. dahliae probe & $\begin{array}{l}\text { [FAM]CACCGCAAGCAGACTCTTGA } \\
\text { AAGCCA [BHQ_1] }\end{array}$ & & & & \\
\hline VTP1-2F & CTCGATCGTCGTCAACC & \multirow{3}{*}{$\begin{array}{l}\text { Trypsin protease } \\
\text { (VTP1) gene }\end{array}$} & \multirow[t]{3}{*}{155} & \multirow{3}{*}{$\begin{array}{l}2 \mathrm{~min} \text { at } 95^{\circ} \mathrm{C} ; 40 \text { cycles of } 30 \mathrm{~s} \\
\text { at } 95^{\circ} \mathrm{C}, 60 \mathrm{~s} \text { at } 58^{\circ} \mathrm{C} \text {, and } 30 \mathrm{~s} \text { at } 72^{\circ} \mathrm{C}\end{array}$} & \multirow[t]{3}{*}{27} \\
\hline VTP1-2R & TGGTGGTGAGAGTGTTG & & & & \\
\hline VTP1-2P & $\begin{array}{l}\text { [FAM]TACGACAACGACTTCGCCATC } \\
\text { [BHQ_1] }\end{array}$ & & & & \\
\hline
\end{tabular}

${ }^{\text {a }}$ Sequence-characterized amplified region (SCAR) from V. dahliae. 